\title{
Assessment of the fishery, growth and mortality characteristics of the cassava croaker, Pseudotolithus senegalensis (Sciaenidae) from coastal waters of Ghana
}

\section{Isaac Okyere ( $\square$ iokyere@ucc.edu.gh )}

Department of Fisheries and Aquatic Sciences, University of Cape Coast, Cape Coast, Ghana https://orcid.org/0000-0001-8725-1555

John Blay

Department of Fisheries and Aquatic Sciences, University of Cape Coast, Cape Coast, Ghana

\section{Research Article}

Keywords: Cassava croaker, Fishery, Growth and mortality, Management

Posted Date: July 16th, 2020

DOl: https://doi.org/10.21203/rs.3.rs-43312/v1

License: (c) (1) This work is licensed under a Creative Commons Attribution 4.0 International License. Read Full License

Version of Record: A version of this preprint was published at Regional Studies in Marine Science on August 23rd, 2020. See the published version at https://doi.org/10.1016/j.rsma.2020.101425. 


\section{Abstract}

This paper reports on the fishery and some population parameters of the cassava croaker (Pseudotolithus senegalensis) at Anlo Beach near Shama ( $5^{\circ} 01^{\prime} \mathrm{N}, 1^{\circ} 37^{\prime} \mathrm{W}$ ) in the Western Region of Ghana. The study was conducted from July 2012 to June 2013 to contribute to information on the dynamics of demersal stocks in the country. Beach seining was the prime fishing method in the area with the fishing season spanning July to March. Catch per unit effort (CPUE), determined as catch per net haul per day was $9.5 \mathrm{~kg}$ per haul in July 2012, $110 \mathrm{~kg}$ per haul in January-February 2013 and $47 \mathrm{~kg}$ per haul in March 2013. The species was absent from the fishery from April 2013 to June 2013. Monthly catches varied from 2,295 kg to $31,500 \mathrm{~kg}$, and specimens of the fish measured $7.5 \mathrm{~cm}$ TL to $105.4 \mathrm{~cm}$ TL and weighed $2.9 \mathrm{~g}$ to $7,634 \mathrm{~g}$. The length-weight relationship of the population was described by the equation: $\mathrm{BW}=0.005 \mathrm{TL}^{3.04}(r=0.99)$, and grouping the fish at $5 \mathrm{~cm}$ class intervals showed modal lengths at 15.0 - 19.9, $35.0-39.9$ and $60.0-64.9 \mathrm{~cm}$ TL. Analysis of the length-frequency distribution using the ELEFAN programme indicated an asymptotic length $\left(L_{\infty}\right)$ of $110.3 \mathrm{~cm} \mathrm{TL}$, a growth coefficient $(K)$ of 0.2 $\mathrm{yr}^{-1}$, and total $(Z)$, natural $(M)$ and fishing $(F)$ mortality coefficients of $0.68 \mathrm{yr}^{-1}, 0.42 \mathrm{yr}^{-1}$, and $0.26 \mathrm{yr}^{-1}$ respectively, for the population. Longevity of the fish was estimated to be 15 years. A low exploitation level of the stock is suggested by the calculated exploitation ratio, $E=0.38$. These population characteristics are compared with those of other West African P. senegalensis populations.

\subsection{Introduction}

Croakers (Family Sciaenidae) are widely distributed along the west coast of Africa from Morocco to Angola (Paugy et al., 2003), and have also been reported from Namibia (Chao and Trewavas, 1990). The cassava croaker Pseudotolithus senegalensis is an economically important demersal fish in Ghana (Koranteng, 1997) as in the fisheries of other West African countries, e.g. Cameroon (Djama and Pitcher, 1989), Nigeria (Anyanwu and Kusemiju, 1990) Benin (Sossoukpe et al., 2013a) and Liberia (Wehye et al., 2017). According to Nunoo and Nascimento (2015), P. senegalensis is the commonest sciaenid in the Gulf of Guinea representing $70 \%$ of the biomass of this group.

Stock assessment survey records show that the biomass of the Sciaenidae declined by $37 \%$ from 2000 to 2006, and mean body size of species has also declined from $50 \mathrm{~cm}$ TL in 1989-90 to 25-30 cm TL in recent times (Nunoo and Nascimento, 2015). Based on these records and other considerations across the West African sub-region, Nunoo (2015) and Nunoo and Nascimento (2015) suggested that $P$. senegalensis and $P$. typus be considered as threatened species. Information on current trends in biomass changes is however not available but reductions in landings and body size of Pseudotolithus spp. have been reported in Cameroon (Djama and Pitcher, 1989), Nigeria (Anyanwu and Kusemiju, 1990) and Benin (Sossoukpe et al., 2013a). Considering the high incidence of juvenile cassava croakers in beach seine landings from Cape Coast waters (Ghana), Blay, Awittor and Agbeko (2006) cautioned the likely negative effect of this fishery on recruitment of juveniles into the adult stocks. 
The study was conducted at Anlo Beach in Shama District (Ghana) where beach seine fishing is the main livelihood of the people. Cast netting, gill netting, and use of crustacean pots are practiced on a smaller scale in the nearby River Pra Estuary. This study therefore examined the fishery, growth, mortality and exploitation of $P$. senegalensis, the commonest species in the catches from the area to provide requisite information for managing the stock.

\subsection{Materials And Methods}

\subsection{Study area}

The study was conducted at Anlo Beach $\left(5^{\circ} 01^{\prime} \mathrm{N}, 1^{\circ} 37^{\prime} \mathrm{W}\right)$, a small village located on a strip of land between the ocean and the wetland associated with the River Pra estuary near Shama in the Western Region of Ghana.

\subsection{Collection of fishery data}

Data on the beach seine fishery for cassava croaker $P$. senegalensis were recorded monthly from July 2012 to June 2013. The beach seine nets used measured $100 \mathrm{~m}$ to $800 \mathrm{~m}$ in length, with about $70 \%$ of the 31 nets encountered measuring averagely $200 \mathrm{~m}$, and comprised 3 to 5 meshes with stretched mesh sizes ranging from $20 \mathrm{~mm}$ to $50 \mathrm{~mm}$; the smallest of which is at the codend. The catch $(\mathrm{kg})$ from the haul of a seine net (usually operated by a group comprising 25 to 55 persons depending on the size of the net), was recorded. Due to the variation in the sizes of the nets, catch per unit effort (CPUE) which was calculated as catch per haul was adjusted to catch per haul of a $200 \mathrm{~m}$ net deployed. Since the management regime in the community allowed for deployment of consistently 11 nets per day although occasionally up to 13 , the mean CPUE was calculated for 11 groups in a day. The total daily catch was determined as the sum of the amount of fish caught by all the seine net groups, and monthly fish catch as the total weight of fish caught in 26 fishing days.

\subsection{Determination of growth and mortality parameters}

Monthly samples of fish were obtained from commercial catches from July 2012 to March 2013, and specimens were measured for total length $(T L)$ and body weight $(B W)$ to the nearest $0.1 \mathrm{~cm}$ and $0.1 \mathrm{~g}$ respectively. The length-weight relationship of the species was established by the least-squares method, and monthly length-frequency distribution was analyzed at $5 \mathrm{~cm}$ class intervals. Estimates of the growth coefficient $K$ ) and the maximum theoretical length $\left(L_{\infty}\right.$ ) were obtained from the ELEFAN programme (Gayanilo et al., 2005) in the FiSAT II software. The parameter $t_{0}$ which refers to the age at which the length of the fish is zero (Gulland, 1983) was estimated from Pauly's (1983) equation:

$\log _{10} t_{0}=-0.3922-0.2752 \log _{10} L_{\infty}-1.038 \log _{10} K$

Longevity $\left(t_{\max }\right)$ of the population was determined as $t_{\max }=3 / K$ (Pauly, 1983), and growth performance index $(\mathbb{Q} \mathbb{Z})$ as $\log _{10} K+2 \log _{10} L_{\infty}$ (Moreau et al., 1986). Total mortality $(Z)$ of the population was 
determined from the catch curve, a plot of the natural logarithm of the numerical proportion of fish belonging to different ages caught by the fishing gear against their relative ages. Natural mortality $(M)$ was estimated from Pauly's (1980a) empirical equation: $\log _{10} M=-0.0066-0.279 \log _{10} L_{\infty}+0.6543 \log _{10}$ $K+0.4634 \log _{10} T$, where $T$ is the mean annual sea surface temperature of the study area. The fishing mortality coefficient $(F)$ was derived from the equation, $Z=F+M$ (Ricker, 1975), and exploitation ratio $(E)$ as $E=F / Z$ (Gulland, 1971).

\subsection{Results}

\subsection{The fishery}

Beach seining was the predominant fishing method at Anlo Beach, a community located near the mouth of the River Pra estuary. Depending on net size, thirty-one groups each comprising 25 to 55 persons fished in the area, however ten to fifteen groups, but regularly eleven groups operated each day as local regulations restricted the number of seine nets in operation at a time. Each group did one haul a day. Fishing occurred throughout the week except on Tuesday, the traditional rest day for fishermen in the country resulting in about 26 fishing days a month. The fishing season commenced from July and ended in March after which fishing was sporadic, by a few individuals for subsistence. Interaction with members of the community revealed this is an annual practice as most fishers go into farming between April and June as an alternate livelihood activity because the low catches at the time make fishing less profitable.

Monthly catches increased from 2,295 kg in July 2012 to a peak of 31,500 kg in January-February 2013 and declining to $11,464 \mathrm{~kg}$ in March (Fig. 1a). The CPUE also increased from $9.51 .1 \mathrm{~kg}$ per haul in July 2012 to a maximum of $110.2 \pm 15.4 \mathrm{~kg}$ per haul in January 2013 and declined to $47.4 \pm 4.6 \mathrm{~kg}$ in March 2013 when commercial fishing ended (Fig. 1b). Croakers were not encountered in subsistence catches from April to June 2013.

\subsection{Length-weight relationship}

The $P$. senegalensis specimens sampled measured $7.5 \mathrm{~cm} T L$ to $105.4 \mathrm{~cm} T L$, and weighed $2.9 \mathrm{~g}$ to 7,634 g. The croaker population showed isometric growth (i.e. the coefficient $b$ was not significantly different from 3.0) in the length-weight relationship described by the equation $B W=0.0054 T L^{3.04}(r=0.99 ; t=1.24$, $P>0.05$ ) (Fig. 2). Isometric growth is inferred if a fish increases proportionally in length, width and depth, while a disproportionate increase in these dimensions is indication of allometric growth (Pauly, 1984).

\subsection{Length-frequency distribution}

The length-frequency distribution of $P$. senegalensis (Fig. 3) showed three size groups with modes at the $15.0-19.9,35.0-39.9$ and $60.0-64.9 \mathrm{~cm}$ TL classes.

Figure 4 shows the monthly length-frequency distribution of the species fitted with the von Bertalanffy growth curve. In July, August and September 2012 the primary mode of the distributions was $35 \mathrm{~cm}$ TL. 
This increased to $60 \mathrm{~cm}$ TL in January 2013 and was maintained in the February and March 2013 samples, suggesting that the samples comprised immigrants, and this may explain the departure of the modes from the growth curve during the period.

\subsection{Growth and mortality parameters}

Analysis of the length-frequency data using the ELEFAN software gave growth parameters of the population as $K=0.2 \mathrm{yr}^{-1}$, and $L_{\infty}=110.3 \mathrm{~cm} T L$. Substituting these parameters in Pauly's (1983) empirical equation resulted in an estimated $t_{0}$ of $-0.59 \mathrm{yr}$. Hence on yearly basis, growth of the cassava croaker population may be described by the von Bertalanffy equation:

$L_{\mathrm{t}}=110.3\{1-\exp [-0.2(t+0.59)]\}$

where $L_{\mathrm{t}}$ is the length of fish at age $t$ (Fig. 5). The fish in this population were estimated to have a longevity $\left(t_{\max }\right)$ of 15 years.

The total mortality $(Z)$ was detrmined only for fish that were fully expoited from the length-converted catch curve for the $P$. senegalensis population (Fig. 6). Regression analysis in the catch curve excluded data points on the ascending portion of the curve representing fish that were not fully recruited into the fishery, and those on the descending part corresponding to fish in the older age groups with low occurrence in the population. Also precluded were from the analysis were the backward-projected points representing small size fish that would have been retained in the net in the absence gear selection and/or incomplete recruitment. The total mortality coefficient $(Z)$ determined from the slope of the regression line for fully exploited fish was $0.68 \mathrm{yr}^{-1}$, and the natural mortality coefficient $(M)$ calculated from Pauly's (1980a) equation by substituting the sea surface temperature of the study area $\left(26.7^{\circ} \mathrm{C}\right)$ was $0.42 \mathrm{yr}^{-1}$.

Therefore, the fishing mortality coeficient $(F=Z-M)$ was $0.26 \mathrm{yr}^{-1}$, and the resulting exploitation ratio $(E)$ was 0.38 .

\subsection{Discussion}

The beach seine fishery at Anlo Beach in the Shama district of Ghana exploits several species of which the cassava croaker, Pseudotolithus senegalensis is the most important, economically. The close proximity of the stock to the River Pra estuary could be attributed to availability of its prey species, mainly fish and shrimps (Blay et al., 2006) in the nearshore waters. Furthermore, sciaenids are reported (Ssentongo and Ansa-Emmin, 1986) to commonly aggregate in coastal waters near estuaries. Information on the characteristics of the fisheries of croakers in other parts of West Africa is however scanty with only a brief mention of the existence of a small scale fishery of the species in Benin (Sossoukpe et al., 2013a).

The maximum observed length $\left(L_{\max }\right)$ of $105.4 \mathrm{~cm}$ TL of the species from Anlo Beach was close to the maximum length (114 cm TL) reported in Fishbase (www.fishbase.org), but significantly longer than the 
maximum lengths of $47 \mathrm{~cm}$ TL to $66 \mathrm{~cm}$ TL found in the coastal waters of Côte d'Ivoire, Benin, Sierra Leone and Liberia (Sossoukpe et al., 2013a; Olapade and Tarawallie, 2014; Tia et al., 2017; Wehye et al., 2017). The length frequency data show the presence of an appreciable proportion of small fish $(<20 \mathrm{~cm})$ in July-August, 2012, and the primary modal length of these samples increased progressively until January-March 2013.

Studies on the breeding periods of some populations of $P$. senegalensis in the Gulf of Guinea show that spawning occurs from March to June, and September to December (Anyanwu, 1990; Sossoukpe et al., 2013b; Olapade and Tarawallie, 2014; Sylla et al., 2016). Although the reproductive biology of the species was not investigated in the present study, the small fish encountered in the July-August 2012 samples may be juvenile recruits from the March-June spawning. It is however unclear whether the present population breeds in September-December as small fish were absent in the January, February and March samples. Specimens were not seen in catches from April to June, a situation that could be ascribed to migration of the fish into deeper waters.

Growth of the cassava croaker population in Ghana was isometric, similar to the populations in Benin (Sossoukpe et al., 2013a) and Côte d'Ivoire (Tia et al., 2017). The growth constant of the fish in the present study $\left(K=0.2 \mathrm{yr}^{-1}\right)$ was not remarkably different from values determined for the Benin (Sossoukpe et al., 2013a) and Liberia (Wehye, et al., 2017) populations which have $K$ values of $0.24 \mathrm{yr}^{-1}$ and $0.13 \mathrm{yr}^{-1}$,respectively. These estimates were however slightly lower than the estimate $\left(K=0.4 \mathrm{yr}^{-1}\right)$ for the Côte d'Ivoire stock (Tia et al., 2017). Hence, in general growth of the species in the Gulf of Guinea is slow. The longer maximum theoretical length $\left(L_{\infty}=110.3 \mathrm{~cm} \mathrm{TL}\right)$ of the Ghana fish compared to specimens in Côte d'Ivoire $\left(L_{\infty}=47.9 \mathrm{~cm}\right)$, Benin $\left(L_{\infty}=51.4 \mathrm{~cm}\right)$ and Liberia $\left(L_{\infty}=66.6 \mathrm{~cm}\right)$ might suggest exposure of the former to better environmental conditions for growth.

It would appear from the VBGF that the Anlo Beach fish would only attain the maximum theoretical length $\left(L_{\infty}=110.3 \mathrm{~cm}\right)$ beyond 20 years of age. Individuals of the species growing to $100 \mathrm{~cm}$ have similarly been associated with long life spans up to 20 years (Nunoo and Nascimento, 2015). The slow growth rate of the croakers at Anlo Beach could also account for the longer period it takes to reach the maximum theoretical length, which suggests a K-selected life history (Pianka, 1970) for the population. Growth performance index of the Ghana stock $(\nabla \square=3.40)$ was also higher than the populations in Benin $(\mathbb{\square}=2.75$; Sossoukpe et al., 2013a), Côte d'Ivoire ( $\mathbb{\square} \square=2.97$; Tia et al., 2017) and Liberia $(\mathbb{\square} \square=2.76$; Wehye et al., 2017) which may explain the larger maximum theoretical length in fish from Ghana.

Fishing mortality coefficient of the Anlo Beach stock $\left(F=0.26 \mathrm{yr}^{-1}\right)$ was lower than that of the populations in Liberia (0.56 $\mathrm{yr}^{-1}$, Wehye et al. (2017) and Benin (3.70 $\mathrm{yr}^{-1}$, Sossoukpe et al., 2013a) which might explain the lower exploitation ratio $(E=0.38)$ for the Ghana population compared to the Liberia $(E=$ $0.60)$ and Benin ( $E=0.84$ ) stocks (ibid). Okyere (2015) estimated $E$ as 0.42 for the large demersal fish community in the study area from ECOPATH with Ecosim analysis (Pauly et al., 2000), which supports the current low exploitation ratio of the $P$. senegalensis stock. This apparent low exploitation could be 
attributed to strict compliance of the local regulation whereby daily fishing is rotated among the thirty-one fishing companies which operate in the area.

\subsection{Conclusion}

From the foregoing it may be concluded that the Anlo Beach $P$. senegalensis population has better growth characteristics than other West African populations, perhaps due to its unique location near the River Pra estuary where food is likely abundant. The level of exploitation of the $P$. senegalensis stock is adequate to sustain the fishery, hence, the current fishing regime in the area should be maintained while encouraging voluntary compliance of local fishery management regulations.

\section{Declarations}

\section{Acknowledgement}

The authors are grateful to the Department of Fisheries and Aquatic Sciences, University of Cape Coast for providing field equipment to undertake this study.

\section{Funding}

This research did not receive any specific grant from funding agencies in the public, commercial, or notfor-profit sectors.

\section{Ethical statement}

This study did not involve experiments on humans and did not use unapproved methods of data collection.

\section{Author contributions}

I. O. designed the research, acquired data-sets and wrote the manuscript, J. B. designed the research, revised the manuscript and supervised the work.

\section{Competing interests}

The authors declare no competing interests.

Disclaimer on trademarks

The mention or use of any trademarks in this study does not imply any affiliation with or endorsement of them.

\section{Data Availability}


The datasets generated and used during this study are available from the corresponding authors on reasonable request.

\section{References}

1. Anyanwu, A. O., 1990. Some aspects of the reproductive biology of the Croakers, Pseudotolithus senegalensis ( $\mathrm{C}$ and $\mathrm{V}$ ) and Pseudotolithus typus (Bleaker) off the coast of Lagos, Nigeria. Journal of Aquatic Sciences, 5, 59-64.

2. Anyanwu, A.O., Kusemiju, K. I., 1990. Food of the croakers Pseudotolithus senegalensis (Cand V) and Pseudotolithus typus (Bleeker) off the coast of Lagos, Nigeria. Journal of Fish Biology, 37(5), 823826. DOI: 10.1111/j.1095-8649.1990.tb02545.x

3. Blay, J. Jr. Awittor, W. K., Agbeko, D., 2006. Seasonal variation in food preference and feeding ecology of two juvenile marine fishes, Pseudotolithus senegalensis (Sciaenidae) and Brachydeuterus auritus (Haemulidae) off Cape Coast, Ghana. West African Journal of Applied Ecology, 9, 149-155. http://dx.doi.org/10.4314/wajae.v9i1.45686

4. Chao, L. N., Trewavas, , 1990. Sciaenidae. In J.C. Quero, J.C. Hureau, C. Karrer, A. Post and L. Saldanha (Eds.), Check-list of the fishes of the eastern tropical Atlantic (CLOFETA) (pp. 813-826). JNICT, Lisbon; SEI, and UNESCO, Paris. Vol. 2.

5. Djama T., Pitcher, T. J., 1989. Comparative stock assessment of two sciaenid species, Pseudotolithus typus (Bleeker, 1863) and Pseudotolithus senegalensis (Valenciennes, 1833) off Cameroon. Fisheries Research, 7, 111-125. https://doi.org/10.1016/0165-7836 (89)90011-8

6. Gayanilo, F. C. Jr., Sparre, P., Pauly, D., 2005. FAO-ICLARM Stock Assessment Tools II (FiSAT II). User's guide. FAO Computerized Information Series (Fisheries). No. 8, revised version. Rome, FAO.168 pp.

7. Gulland, J. A., 1971. The fish resources of the oceans. FAO/Fishing News Books, Surrey, UK.

8. Gulland, J. A., 1983. Fish Stock Assessment: a manual of basic methods. Chichester, U.K., Wiley Interscience, FAO/Wiley series on food and agriculture, Vol. I, 223 pp.

9. Koranteng, K. A., 1997. Marine fishery resources of Ghana's coastal zone. In S. M. Evans, C. J. Vanderpuye \& A. K. Armah (Eds.), The coastal zone of West Africa: problems and management. Proceedings of an International Seminar 23-28 March, 1996, Accra, Ghana.

10. Moreau, J., Bambino, C., Pauly, D., 1986. Indices of overall growth performance of 100 tilapia (Cichlidae) populations. In J. N. Maclean, L. B. Dizon \& L. V. Hesillas, The First Asian Fisheries Forum (pp. 201-206). Manila, Philippines: Asian Fisheries Society.

11. Nunoo, F., 2015. Pseudotolithus typus. The IUCN Red List of Threatened Species 2015 : http://dx.doi.org/10.2305/IUCN.UK.2015-4.RLTS.T49218074A49224503.en

12. Nunoo, F., Nascimento, J., 2015. Pseudotolithus senegalensis. The IUCN Red List of Threatened Species 2015: http://dx.doi.org/10.2305/IUCN.UK.2015-4.RLTS.T49217798A49222499.en

13. Olapade, J.O., Tarawallie, S., 2014. The length-weight relationship, condition factor and reproductive biology of Pseudotolithus senegalensis (Valenciennes, 1833) (croakers), in Tombo Western Rural 
District of Sierra Leone. African Journal of Food, Agriculture, Nutrition and Development, 14 (6), 2176 $-2189$.

14. Okyere, I., 2015. Assessment of aquatic ecosystems, the fishery and socio-economics of a coastal area in the Shama District, Ghana. PhD Thesis, University of Cape Coast. 227 pp.

15. Pauly, D., 1980. On the interrelationships between natural mortality, growth parameters, and mean environmental temperature in 175 fish stocks. ICES Journal of Marine Science, 39 (2), 175-192. https://doi.org/10.1093/icesjms/39.2.175

16. Pauly, D., 1983. Some simple methods for assessment of tropical fish stocks. FAO Fisheries Technical Paper 234, 52 pp.

17. Pauly, D. 1984. Fish Population Dynamics in Tropical Waters: a manual for use with programmable calculators. ICLARM Studies and Reviews 8, $325 \mathrm{p}$.

18. Pauly, D., Christensen, V., Walters, C., 2000. Ecopath, Ecosim, and Ecospace as tools for evaluating ecosystem impact of fisheries. ICES journal of Marine Science, 57 (3), 697-706. https://doi.org/10.1006/jmsc.2000.0726

19. Paugy, D., Lévêque, C., Teugels, G. G., 2003. The fresh and brackish water fishes of West Africa. II. IRD Editions, Publications Scientifiques du Muséum, MRAC, 815pp.

20. Pianka, E. R. (1970). On r-and K-selection. The American Naturalist, 104 (940), 592-597. https://doi.org/10.1086/282697

21. Ricker, W. E., 1975. Computation and interpretation of statistics of fish populations. Bulletin of the Fisheries Research Board of Canada. 191. 382 pp.

22. Sossoukpe, E., Nunoo, F.K.E., Adite, A., 2013b. Population structure and reproductive parameters of the cassava croaker, Pseudotolithus senegalensis (Pisces, Valenciennes, 1833) in nearshore waters of Benin (West Africa) and their implications for management. International Journal of Development Research, 3 (9), 37-45.

23. Sossoukpe, E., Nunoo, F. K. E., Ofori-Danson, P. K., Fiogbe, E. D., Dankwa, H. R., 2013a. Growth and mortality parameters of senegalensis and P. typus (Sciaenidae) in nearshore waters of Benin (West Africa) and their implications for management and conservation. Fisheries Research, 137, 71-80. https://doi.org/10.1016/j.fishres.2012.08.020

24. Ssentongo, G. W., Ansa-Emmin, M., 1986. Marine fishery resources of Sierra Leone: A review of exploited fish stocks. CECAF/ECAF Series (FAO).

25. Sylla, S., Tia, C. B., Kouakoua, K. F., Kouamea, A. C., Kouamelan P. E., Atse, B. C., 2016. Aspect of reproductive biology of the cassava croaker, Pseudotolithus senegalensis (Valenciennes, 1833) of Ivory Coast continental shelf. Scientific Journal of Biological Sciences, 5 (7), 167-173.

26. Tia, C. B., Konan, K. J., Sylla, S. Kouamelan, E. P., Atse, B. C., 2017. Population Parameters and Stock Assessment of the Cassava Croaker Pseudotolithus senegalensis (Valenciennes, 1833) in the Coastal Waters of Côte d'Ivoire. International Journal of Science and Research Methodology, 6 (2), 79-95. 
27. Wehye, A. S., Ofori-Danson, P. K., Lamptey, A. M., 2017. Population Dynamics of Pseudotolithus senegalensis and Pseudotolithus typus and their Implications for Management and Conservation within the Coastal Waters of Liberia. Fisheries and Aquaculture Journal, 8 (2), 1A.

\section{Figures}
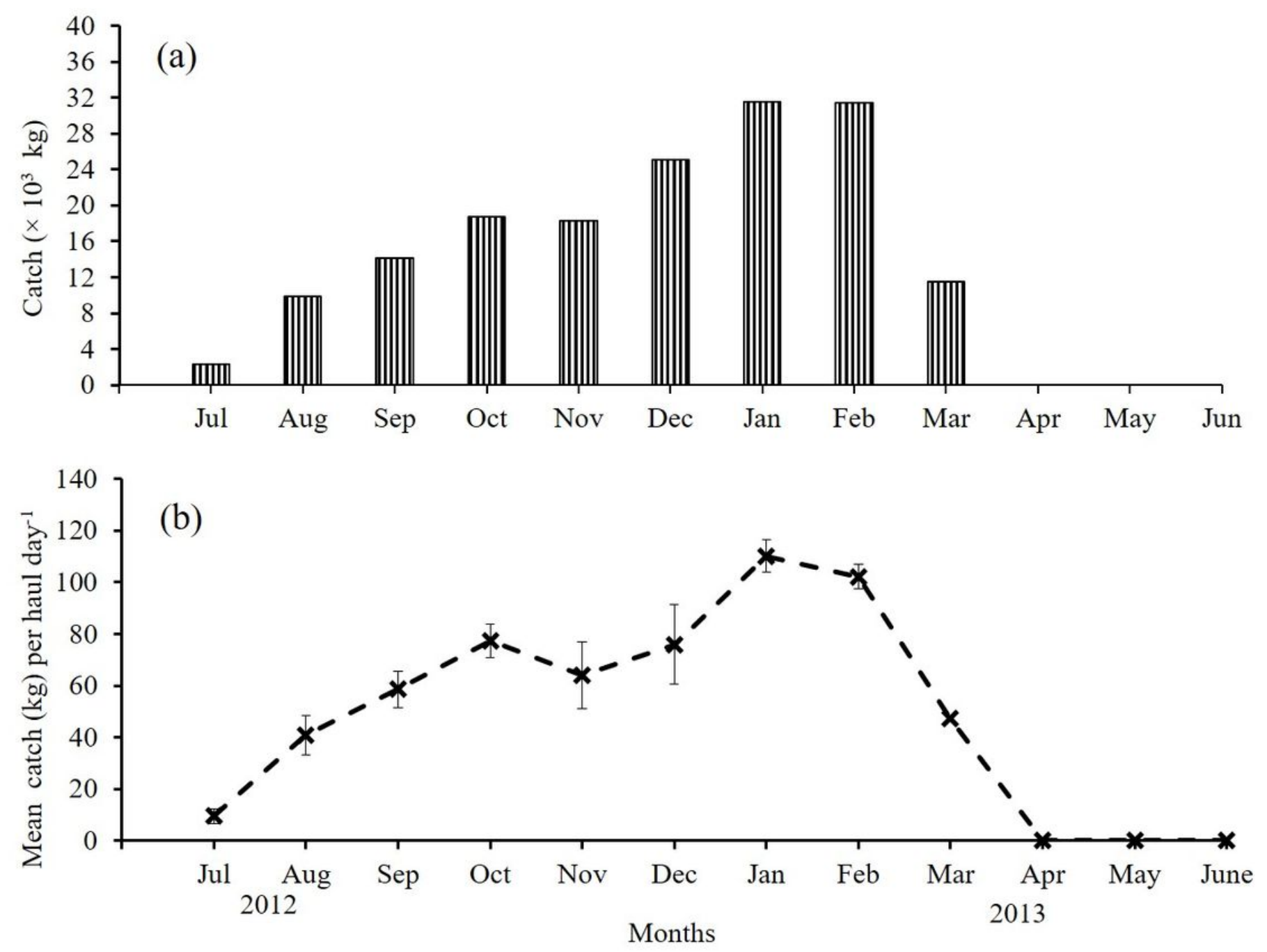

Figure 1

Monthly (a) total catch, and (b) mean CPUE of Pseudotholithus senegalensis at Anlo Beach 


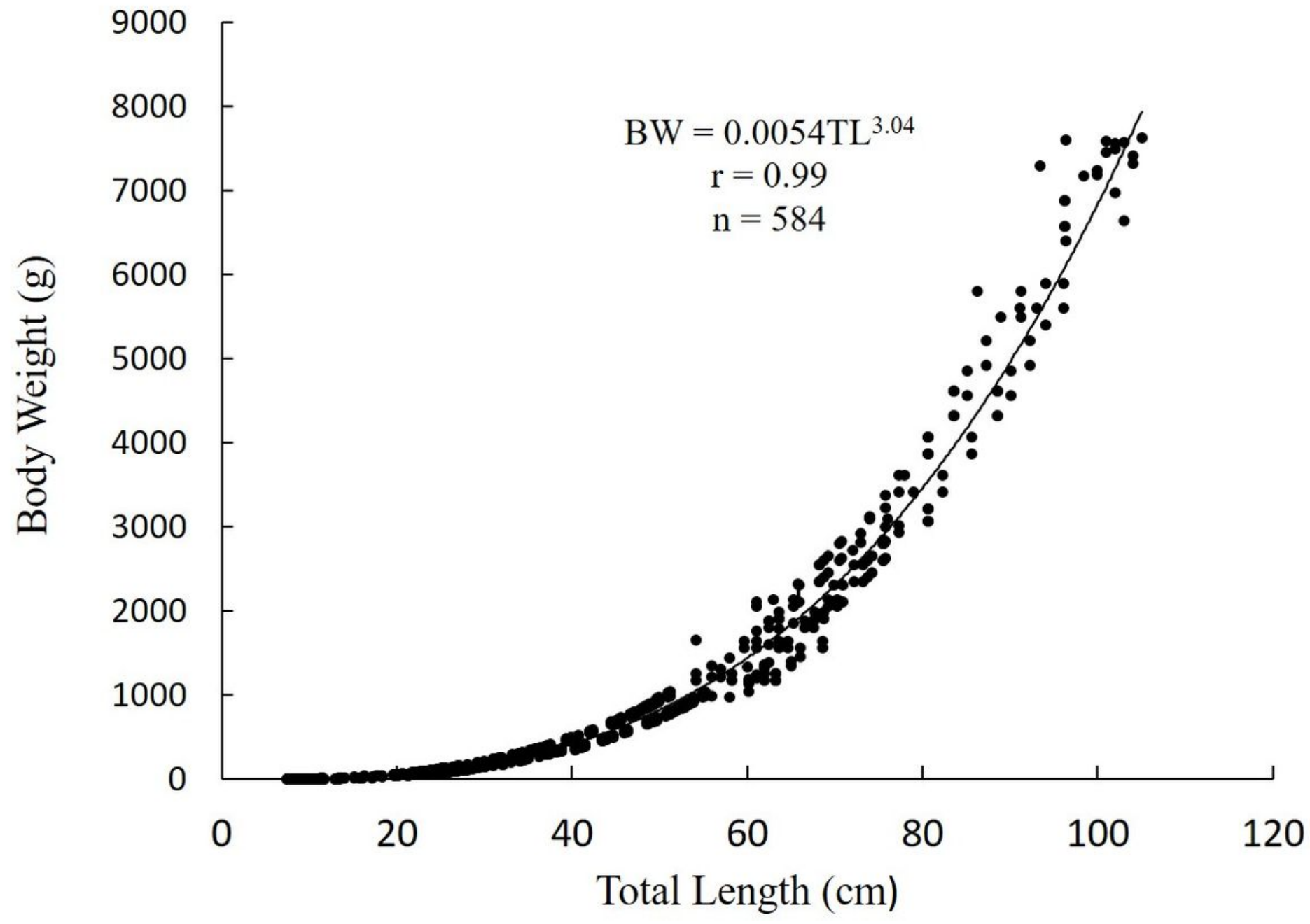

Figure 2

Length-weight relationship of P. senegalensis population from Anlo Beach 


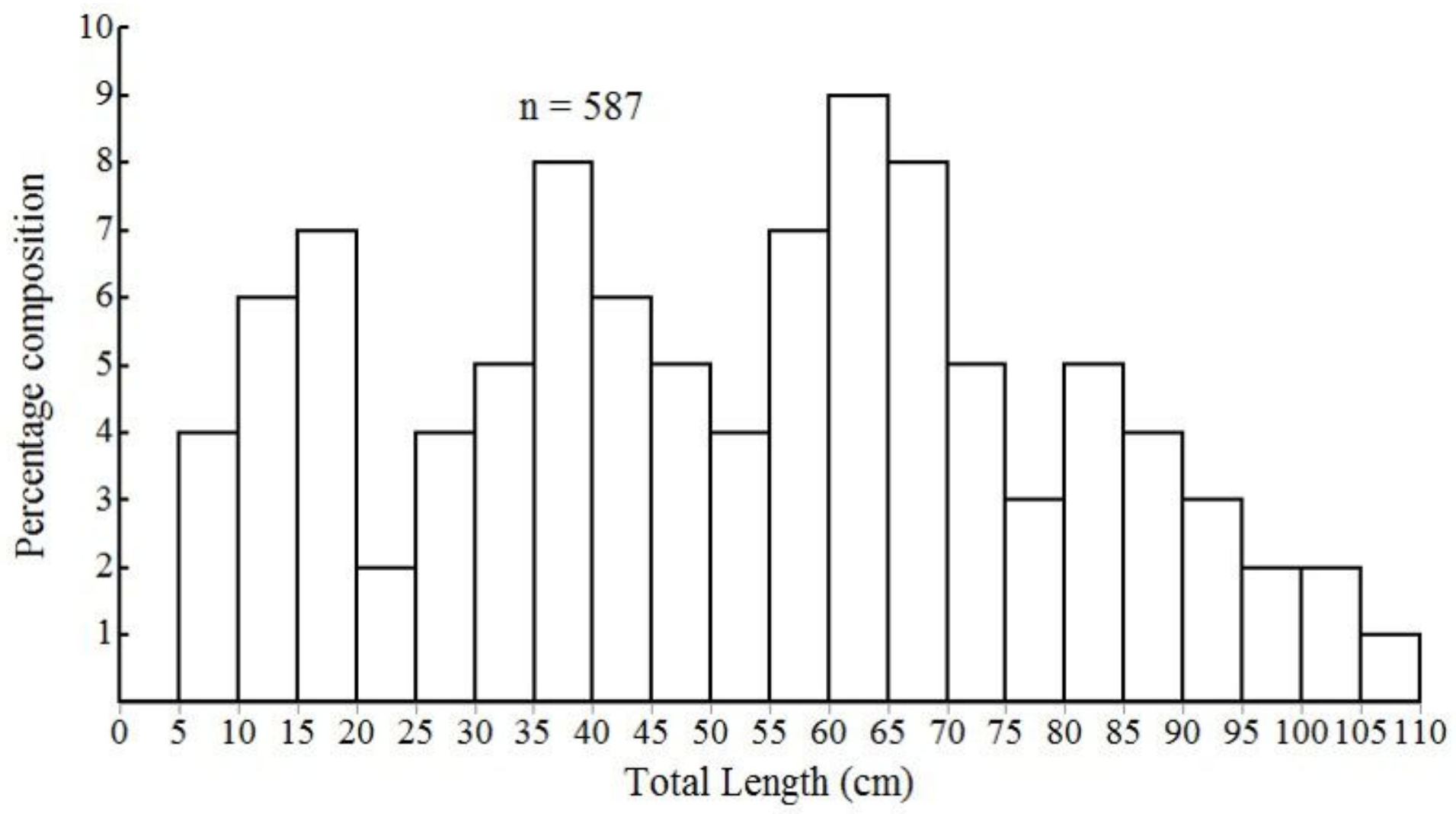

Figure 3

Length-frequency distribution of P. senegalensis from Anlo Beach

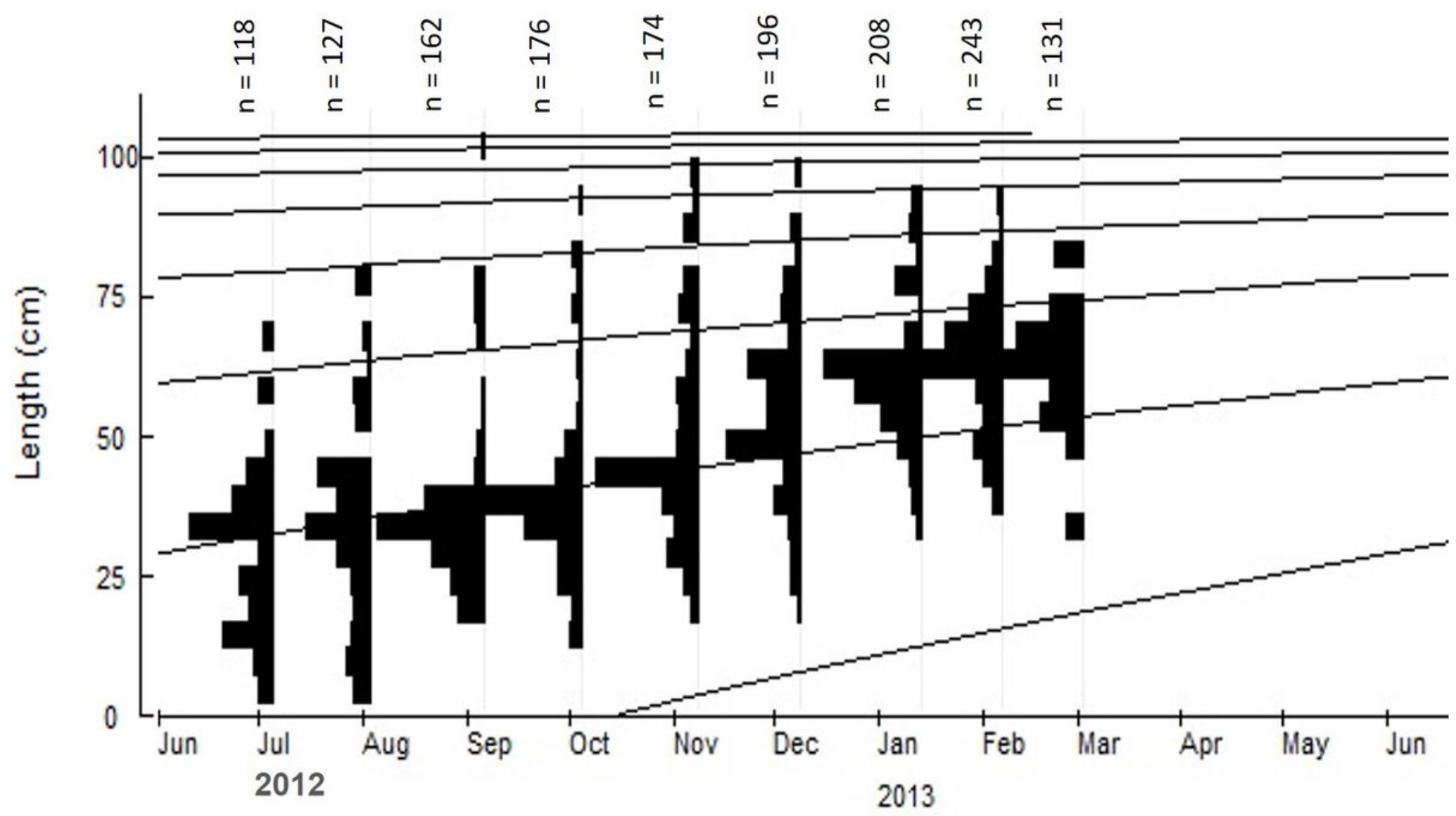


Figure 4

Monthly length-frequency distribution of P. senegalensis from Anlo Beach fitted with the growth curve from ELEFAN suite of FiSAT II routine ( $\mathrm{n}=$ sample size)

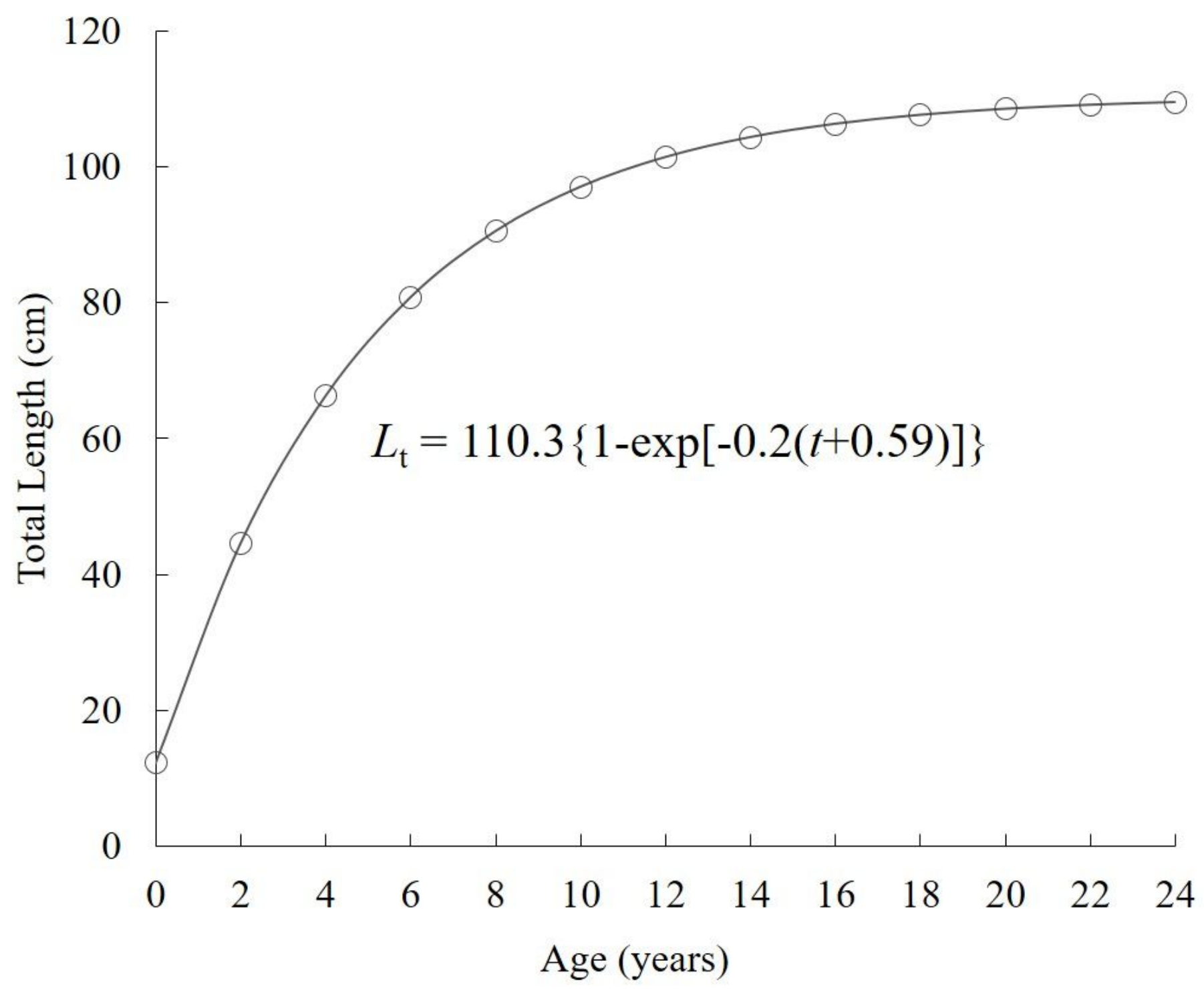

Figure 5

The von Bertalanffy growth curve for Pseudotolithus senegalensis from Anlo Beach 


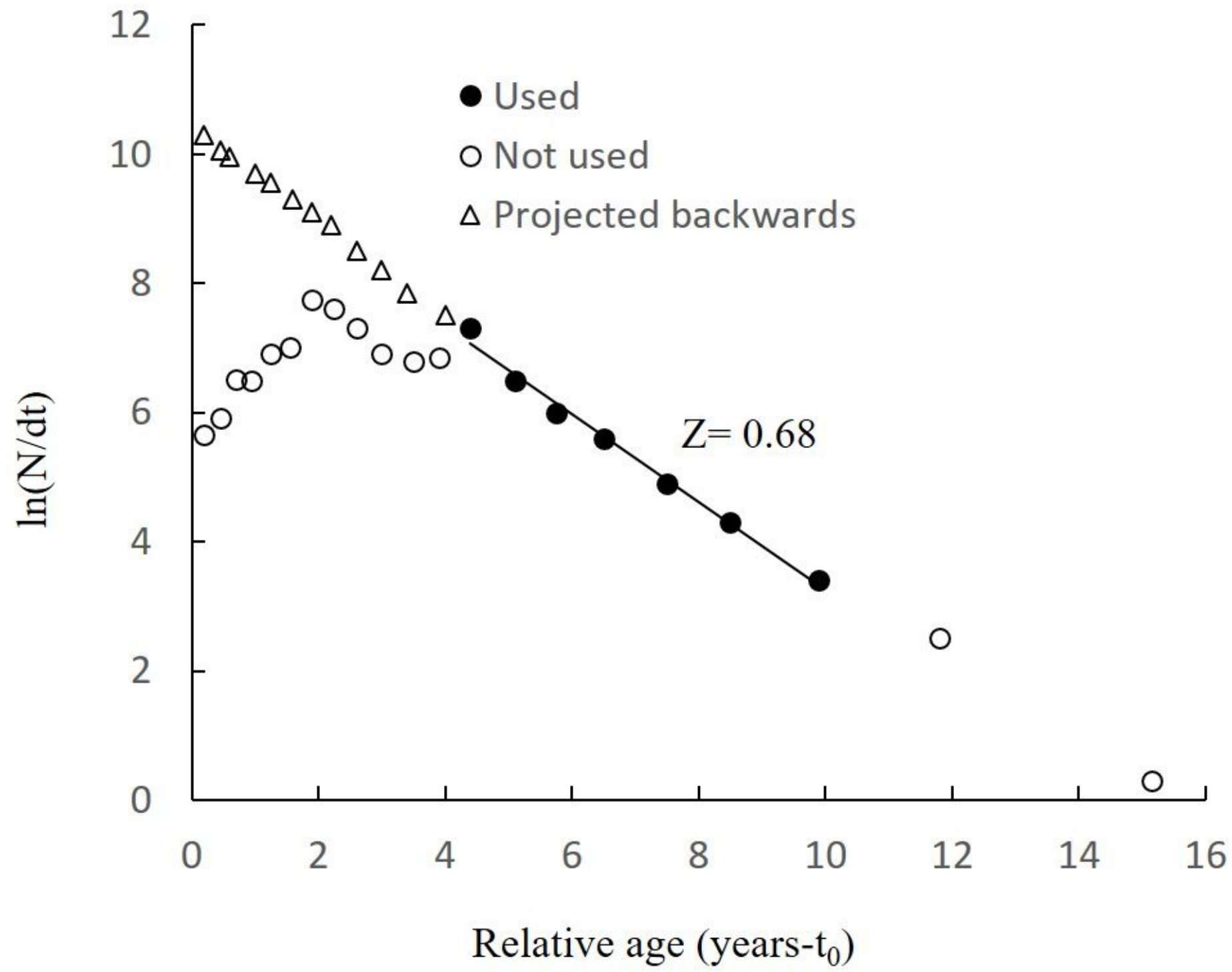

Figure 6

Length-converted catch curve for Pseudotolithus senegalensis from Anlo Beach based on the lengthfrequency data from July 2012 to March 2013 